\begin{tabular}{lll}
\hline$y$ & Jurnal Teknologi Kimia Unimal & $\begin{array}{l}\text { Jurnal } \\
\text { Teknologi } \\
\text { Kimia } \\
\text { Unimal }\end{array}$ \\
\hline
\end{tabular}

\title{
Pengaruh Tekanan Transmembran dan Konsentrasi Chemical Cleaning Agent (NaOH) pada Penyisihan Fosfat dari Limbah Laundry dengan Membran Ultrafiltrasi Aliran Cross Flow
}

\author{
Syarfi Daud ${ }^{1)}$, Muhammad Reza ${ }^{2)}$ Eqiu Alkahfi Tarif ${ }^{3)}$ \\ ${ }^{1,2,3)}$ Laboratorium Pengendalian dan Pencegahan Pencemaran Lingkungan \\ Program Studi Teknik Lingkungan, Fakultas Teknik Universitas Riau \\ Kampus Bina Widya Jl. HR. Soebrantas Km. 12,5 Simpang Baru, \\ Panam, Pekanbaru 28293 \\ email: syarfidaud @gmail.com
}

\begin{abstract}
The rapid economic development and community activities increasingly crowded cause appearance laundry business that effect on the environment. Ultrafiltration membrane is one of wastewater treatment technologies, but membranes have limitations such as the occurrence of the phenomenon of concentration polarization and fouling. The research objective of this study the effect of variations in transmembrane pressure against the rejection percentage Phosphate and the effect of variations in transmembrane pressure, concentration of washing of the efficiency and effectiveness of washing the membrane. the concentration of the washing of the efficiency and effectiveness of washing the membrane. The process of ultrafiltration membranes and membrane chemical washing wastewater laundry do with variations in pressure of 1 bar, 2 bar, and 3 bar. Variation of chemical cleaning agent concentration of $1 \%, 1.5 \%$ and $2 \%$, rinsing with distilled water for 30 minutes, filtering wastewater laundry for 120 minutes, and washing using chemical cleaning agent (NaOH) for 30 minutes. Results highest percentage of rejection was $82.9 \%$ for Phosphate parameters in transmembrane pressure of 3 bar. The highest washing efficiency of the value of Flux Recovery (FR) gained $81.9 \%$, and the value of resistance of Removal (RR) gained $82.59 \%$ with a concentration of $2 \%$ in the transmembrane pressure of 3 bar. The highest leaching effectiveness obtained at $50.21 \%$ with a concentration of $2 \%$ and a transmembrane pressure of 3 bar.
\end{abstract}

Keywords: ultrafiltration membrane, fouling, transmembrane pressure, efficiency of washing, effectiveness of washing

\section{Pendahuluan}

Limbah laundry sering dibuang ke lingkungan tanpa melalui pengolahan sebelunya. Limbah laundry dalam jumlah yang besar masuk ke badan air akan 
mempengaruhi kualitas air. Dampak pengaruh kualitas air akan mempengaruhi ekosistem aquatik serta kesehatan manusia.

Limbah laundry mengandung fosfat $9,9 \mathrm{mg} / \mathrm{L}$, TSS $35 \mathrm{mg} / \mathrm{L}$, COD 280 mg/L dan BOD $_{5} 195$ mg/L [Sostar-Turk, 2004]. Sumber bahan pencemar berasal dari pemakaian deterjen sebagai bahan pencuci. Deterjen digunakan karena memiliki daya cuci yang baik dan tidak terpengaruh kesadahan air, akan tetapi memiliki kandungan fosfat yang cukup tinggi karena fosfat merupakan bahan pembentuk utama dalam deterjen [Rosariawari, 2010].

Kehadiran fosfat yang cukup besar dalam badan air dapat menyebabkan terjadinya fenomena eutrofikasi. Keadaan ini menyebabkan kualitas air menjadi menurun, karena rendahnya konsentrasi oksigen terlarut bahkan sampai batas nol, sehingga menyebabkan kematian mahluk hidup air seperti ikan dan spesies lain yang hidup di air [Masqudi, 2004].

Secara konvensional pengolahan limbah loundry dapat dilakukan secara secara kimia dengan menggunakan alum, penggunaan alum masih menyisakan banyak tantangan. Dosis alumunium yang berlebih berbahaya bagi manusia dan hewan ternak. Penyakit ginjal dan alzheimer (pikun) adalah penyakit yang disebabkan oleh alumunium yang tinggi konsentrasinya dalam air. Pengolahan secara biologi untuk limbah cair umum dilakukan, namun kendalanya di lingkungan perkotaan yang padat penduduk persoalan tempat menjadi kendala karena proses biologi membutuhkan tempat yang besar.

Toknologi membran kini penggunaannya semakin meluas termasuk dalam bidang pengolahan limbah. Teknologi membran memiliki banyak keunggulan dalam pemakaiannya anatara lain ramah lingkungan, tingkat penyisihan yang tinggi, lebih ekonomis, dan membutuhkan tempat relatif kecil. [Idris dkk, 2007]. Disisi lain penggunaan memmbran sebagai filter masih mengalami kendala teruma masalah fouling.

Fouling terjadi karena akumulasi material yang tertahan pada membran. Fouling dapat direduksi dengan tindakan pencucian menggunakan chemical agent cleaning seperti $\mathrm{NaOH}$ [Scott, 1995]. 
Total fosfat merupakan salah satu parameter penting dalam pengukuran kualitas limbah loundry. Baku mutu Parameter fosfat mengacu pada Permen LH No 5 Tahun 2014 tentang baku mutu limbah cair bagi kegiatan domestik.

Variabel penelitian yang diduga berpengaruh pada proses membran dan pencucian membran adalah tekanan transmemberan dan konsentrasi bahan pencuci membran. Efektifitas pencucian kimia dilakukan dengan mempelajari fluk recovery dan resisten Removal.

\section{Bahan dan Metode}

\subsection{Bahan penelitian}

Limbah laundry, Natrium Hidroksida $(\mathrm{NaOH})$, dan Aquadest.

\subsection{Alat penelitian}

Modul membran ultrafiltrasi (Polysulfon), pompa diafragma, timbangan analitik, stopwatch, gelas ukur $100 \mathrm{ml}$ dan $1000 \mathrm{ml}$, beker gelas, ember penampung, dan jerigen ukuran $25 \mathrm{~L}$.

\subsection{Proses Filtrasi}

Pengukuran volume permeat aquades dari umpan selama 30 untuk mendapatkan nilai Jwi. Dilanjutkan dengan filtrasi air limbah laundry selama 120 menit untuk mendapatkan nilai Jf. Kemudian dilakukan flushing dengan aquades lagi selama 30 menit untuk mendapatkan nilai Jww. Pencucian dengan variasi konsentrasi bahan pencuci $\mathrm{NaOH} 1 \%, 1,5 \%$, dan $2 \%$ aliran counter flow. Selanjutnya dilakukan flushing dengan aquades selama 30 menit dengan aliran current flow untuk mendapatkan nilai Jwc. Terakhir dilakukan filtrasi dengan limbah cair laundry selama 120 menit untuk mendapatkan nilai Jf'.

\section{Hasil dan Diskusi}

\subsection{Pengaruh Tekanan Transmembran terhadap Tingkat Rejeksi}

Kinerja membran ultrafiltrasi dalam menyisihkan parameter Fosfat dari air limbah laundry dapat dilihat dari nilai persentase rejeksi. Nilai persentase rejeksi diperoleh dari selisih antara Fosfat sebelum dengan sesudah penyaringan. Hasil perhitungan persentase rejeksi dilihat pada Gambar 1. 


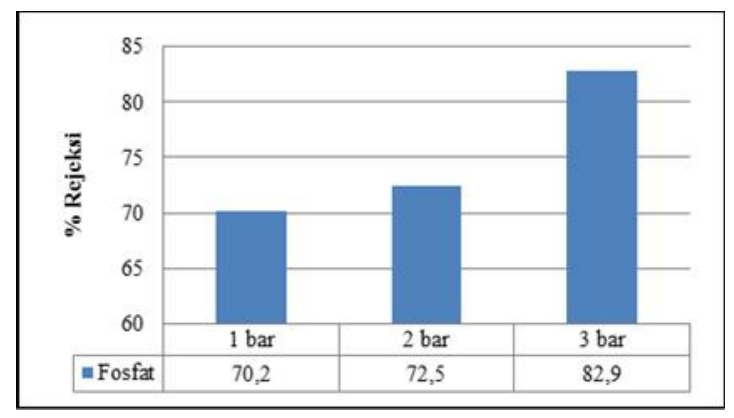

Gambar 1 Hubungan \% Rejeksi terhadap Tekanan Transmembran

Dari Gambar 1 dapat dilihat bahwa persentase rejeksi tertinggi untuk parameter Fosfat didapat pada tekanan transmembran 3 bar yaitu sebesar 82,9\%.

\subsection{Pengaruh Tekanan Transmembran terhadap Fluks Permeat}

Variasi tekanan transmembran digunakan untuk mengetahui pengaruh perubahan tekanan terhadap fluks seperti pada Gambar 2.

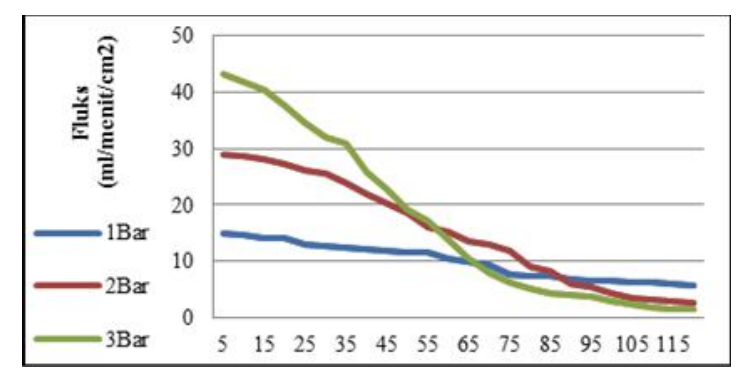

Gambar 2 Pengaruh Tekanan Transmembran terhadap Fluks

Gambar 2 memperlihatkan terjadinya perbedaan fluks yang dihasilkan pada masing-masing tekanan transmembran. Fluks cenderung menurun dengan meningkanya waktu filtrasi. Fluks rata meningkat dengan naiknya tekanan, fluks terbesar diperoleh pada tekanan transmembran 3 bar sebesar $43,84 \mathrm{ml} / \mathrm{menit} . \mathrm{cm}^{2}$ diikuti dengan tekanan 2 bar sebesar 28,87 ml/menit.cm² dan 1 bar sebesar 14,83 $\mathrm{ml} / \mathrm{menit} . \mathrm{cm}^{2}$.

\subsection{Pengaruh Tekanan Transmembran dan Konsentrasi Bahan Kimia terhadap Tingkat Efisiensi Pencucian}

Efisiensi dilihat dari Fluks Recovery (FR) dan Resistant Removal (RR). Hubungan fluks recovery terhadap konsentrasi bahan pencuci dan tekanan seperti pada Gambar 3 dan 4. 


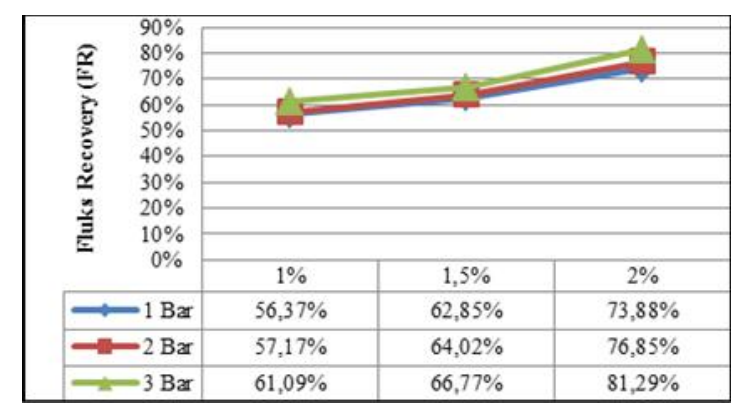

Gambar 3 Nilai FR dengan Bahan Pencuci $\mathrm{NaOH}$ terhadap Tekanan Transmembran

Dari Gambar 3 dapat dilihat nilai Fluks Recovery (FR) tertinggi didapat pada konsentrasi bahan pencuci $2 \%$ dengan tekanan transmembran 3 bar yaitu sebesar $81,29 \%$, diikuti dengan tekanan 2 bar pada konsenstrasi bahan pencuci $2 \%$ sebesar 76,85\% dan tekanan 1 bar pada konsentrasi bahan pencuci $2 \%$ sebesar $73,88 \%$.

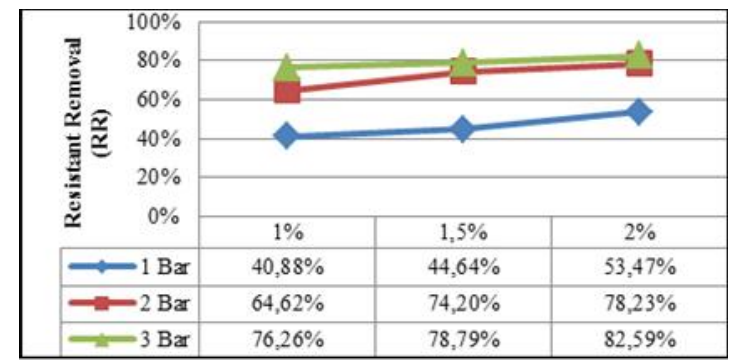

Gambar 4 Nilai RR dengan Bahan Pencuci $\mathrm{NaOH}$ terhadap Tekanan Transmembran

Gambar 4 memperlihatkan naiknya nilai persentase Resistant Removal (RR), didapat nilai RR tertinggi pada konsentrasi bahan pencuci $2 \%$ dengan tekanan transmembran 3 bar yaitu sebesar 82,59\%.

\subsection{Pengaruh Tekanan Transmembran dan Konsentrasi Bahan Kimia terhadap Tingkat Efektifitas Pencucian}

Efektifitas pencucian kimia dapat dilihat dari nilai perbandingan antara nilai rata-rata fluks sebelum dilakukan pencucian dan nilai rata-rata fluks setelah 
dilakukan proses pencucian menggunakan larutan pencuci $\mathrm{NaOH}$.

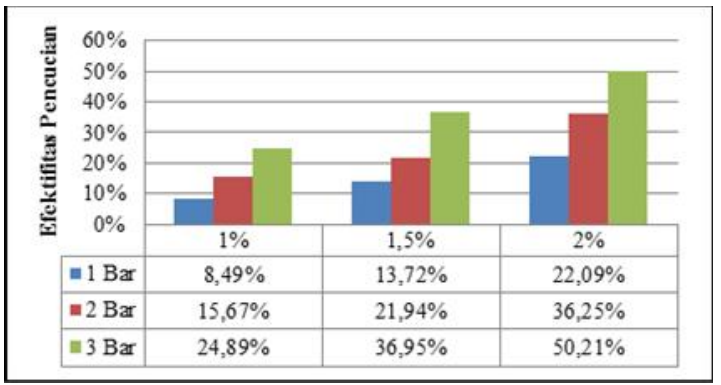

Gambar 5 Grafik nilai efektifitas pencucian dengan bahan kimia $\mathrm{NaOH}$

Dari Gambar 5 dapat dilihat nilai efektifitas pencucian tertinggi diperoleh dengan konsentrasi bahan pencuci $2 \%$ dan tekanan transmembran 3 bar yaitu sebesar 50,21\%. Persentase nilai efektifitas pencucian cenderung naik saat konsentrasi bahan pencuci dan tekanan transmembran dinaikkan.

\section{Simpulan}

1 Kinerja membran ultrafitrasi dalam mengolah limbah laundry untuk persentase rejeksi tertinggi parameter Fosfat mencapai 82,9\%.

2 Nilai fluks tertinggi pada tekanan transmembran 3 bar mencapai 43,84 $\mathrm{ml} / \mathrm{menit}_{\mathrm{cm}} \mathrm{cm}^{2}$, dan fluks terendah didapat pada tekanan transmembran $1 \mathrm{bar}$ sebesar 14,83 $\mathrm{ml} / \mathrm{menit}_{\mathrm{cm}} \mathrm{cm}^{2}$.

3 Efisiensi pencucian tertinggi berdasarkan parameter nilai Fluks Recovery (FR) mencapai 81,29\%, berdasarkan nilai Resistant Removal (RR) mencapai $82,59 \%$ dari bahan pencuci $\mathrm{NaOH}$ dengan konsentrasi $2 \%$ dan pada tekanan transmembran 3 bar. Efektifitas pencucian tertinggi mencapai 50,21\% untuk bahan pencuci $\mathrm{NaOH}$ dengan konsentrasi $2 \%$ dan tekanan transmembran 3 bar.

\section{Daftar Pustaka}

Idris, A., Norashikin, M. Z., Noordin, M. Y. 2007. Synthesis, characterization and performance of asymmetric polyethersulfone (PES) ultrafiltration membranes with polyethylene glycol of different molecular weights as additives, Desalination, 207, 324-339. 
Kazemimoghadam, M, dan Mohammadi, T. 2006. Chemical Cleaning of Ultrafiltration Membran in Milk Industry. Desalination 204. 213-218.

Keputusan Menteri Lingkungan Hidup No. 5 /MENLH/2014. Tentang Baku Mutu Limbah Cair Bagi Kegiatan Domestik.

Kristanto. 2002. Pencemaran Limbah Cair. Yudistira. Jakarta.

Masqudi, A. 2004. Penurunan Senyawa Fosfat Dalam Air Limbah Buatan Dengan Proses Adsorpsi Menggunakan Tanah Halosit. Majalah IPTEK. Jakarta.

Mulder, M. 1996. Basic Principles of Membrane Technology. Kluwer Academic Publisher. USA.

Notodarmojo, S. dan A. Deniva. 2004. Penurunan Zat Organik dan Kekeruhan Menggunakan Teknologi Membran Ultrafiltrasi dengan Sistem Aliran Dead-End (Studi Kasus: Waduk Saguling, Pa-dalarang). PROC. ITB Sains \& Tek. Vol. 36 A, No. 12004 hal. 63-82. Fakultas Teknik Sipil dan Perencanaan ITB. Bandung.

Rosariawari, F. 2010. Efektifitas Multivalen Metal Ions Dalam Penurunan Kadar Phospat Sebagai Bahan Pembentuk Deterjen. Envirotek : Jurnal Ilmiah Teknik Lingkungan, Vol. 2, No.1. Program Studi Teknik Lingkungan Ftsp Universitas Pembangunan Nasional. Surabaya.

Scott, K. 1995. Handbook of Industrial Membranes. edisi ke-1, Elsevier Advanced Technology. Oxford. hal 78-528.

Sostar-Turk, S., Petrini, I., dan Simoni, M., (2005), Laundry wastewater treatment using coagulation and membrane filtration, Resources, Conservation and Recycling, 44, 185-196.

Wenten, I, G. 2002. Teknologi Membran untuk Pemanfaatan Kembali Limbah Air Buangan Laundry. Departemen Teknik Kimia Institut Teknologi Bandung. 